\title{
Determining the gelation temperature of $\beta$-lactoglobulin using in situ microscopic imaging
}

\author{
Hee-Dong Woo, ${ }^{*}$ Tae-Wha Moon, ${ }^{*}$ Sundaram Gunasekaran, $\dagger^{1}$ and Sanghoon Ko $\ddagger^{1}$ \\ *Department of Agricultural Biotechnology, Seoul National University San 56-1, Sillim-Dong, Gwanak-Gu, Seoul 151-921, Republic of Korea \\ †Department of Biological Systems Engineering, University of Wisconsin-Madison, 460 Henry Mall, Madison 53706 \\ ‡Department of Food Science and Technology, Sejong University, 98 Gunja-Dong, Gwangjin-Gu, Seoul 143-747, Republic of Korea
}

\section{ABSTRACT}

Evolution of microstructure during heat-induced gelation of $\beta$-lactoglobulin ( $\beta$-LG) was investigated in situ using confocal laser scanning microscopy at various gel-preparation conditions: $\mathrm{pH}=2,5$, and 7 ; protein content $=5,10$, and $15 \%$; and salt $(\mathrm{NaCl})$ content $=$ $0,0.1$, and $0.3 M$. The number and area of evolving $\beta-L G$ clusters were observed as a function of time and temperature and the data were fitted to a log-normal model and sigmoid model, respectively. The gelation temperature $\left(\mathrm{T}_{\text {gel }}\right)$ of the $\beta$-LG system was determined from both the number $\left(\mathrm{T}_{\mathrm{gel} / \mathrm{N}}\right)$ and total area $\left(\mathrm{T}_{\mathrm{gel} / \mathrm{A}}\right)$ of $\beta-\mathrm{LG}$ clusters versus temperature data. The range of $\mathrm{T}_{\mathrm{gel} / \mathrm{N}}$ and $\mathrm{T}_{\mathrm{gel} / \mathrm{A}}$ values for all the cases was 68 to $87^{\circ} \mathrm{C}$. The effect of $\mathrm{pH}$ was the most dominant on $\mathrm{T}_{\mathrm{gel} / \mathrm{N}}$ and $\mathrm{T}_{\mathrm{gel} / \mathrm{A}}$, whereas the effects of $\beta-\mathrm{LG}$ and salt contents were also statistically significant. Therefore, the combined effect of protein concentration, $\mathrm{pH}$, and salt content is critical to determine the overall gel microstructure and $\mathrm{T}_{\text {gel }}$. The $\mathrm{T}_{\text {gel } / \mathrm{N}}$ and $\mathrm{T}_{\text {gel } / \mathrm{A}}$ generally agreed well with $\mathrm{T}_{\text {gel }}$ determined by dynamic rheometry $\left(\mathrm{T}_{\mathrm{gel} / \mathrm{R}}\right)$. The correlations between $\mathrm{T}_{\mathrm{gel} / \mathrm{N}}$ and $\mathrm{T}_{\mathrm{gel} / \mathrm{A}}$ versus $\mathrm{T}_{\mathrm{gel} / \mathrm{R}}$ were 0.85 and 0.72 , respectively. In addition, $\mathrm{T}_{\mathrm{gel} / \mathrm{N}}$ and $\mathrm{T}_{\mathrm{gel} / \mathrm{A}}$ values compared well with $\mathrm{T}_{\mathrm{gel} / \mathrm{R}}$ values reported in the literature. Based on these results, $\mathrm{T}_{\mathrm{gel} / \mathrm{N}}$ determined via in situ microscopy appears to be a fairly good representative of the traditionally measured gelation temperature, $\mathrm{T}_{\mathrm{gel} / \mathrm{R}}$.

Key words: gelation temperature, $\beta$-lactoglobulin, confocal laser scanning microscopy, microstructure

\section{INTRODUCTION}

The gelation of globular proteins is an irreversible thermal process starting from the unfolding of protein molecules to the formation of a 3-dimensional (3D) intermolecular matrix structure. The intermolecular

\footnotetext{
Received March 11, 2013.

Accepted June 9, 2013.

${ }^{1}$ Corresponding authors: guna@wisc.edu and sanghoonko@sejong. ac.kr
}

aggregation and matrix formation affect gel properties, including gelation temperature $\left(\mathbf{T}_{\text {gel }}\right)$. Microscopic study is helpful to understand macroscopic properties during sol-gel transition of aqueous globular proteins. Appearance, texture, and $\mathrm{T}_{\text {gel }}$ of heat-induced protein gels are strongly influenced by the gel microstructure (Emmons et al., 1980; Holcomb, 1991). The advances in microscopic techniques, such as confocal laser scanning microscopy (CLSM), which can help probe in situ changes in the microstructure, has led to several investigations (Heinemann et al., 2002; Ko and Gunasekaran, 2007; Ako et al., 2009; Ko and Gunasekaran, 2009). Confocal laser scanning microscopy has several advantages for studying gel microstructure because (1) dehydration is usually unnecessary for specimen preparation, (2) optical sectioning of the specimen observes in situ gel microstructure, and (3) gel microstructure can be continuously monitored.

During heat-induced gelation of globular proteins, the protein molecules are not discernible in CLSM at the initial heating period due to the limited resolution of CLSM. However, with time, the ensuing intermolecular aggregation forms protein clusters large enough to be visible on the micrographs. The number and size of these protein clusters grow, and after some time, many of the scattered clusters begin to merge and subsequently form an interconnected 3D network. The inception of the formation of this 3D network is considered the gel point, and the corresponding temperature is the $T_{\text {gel }}$. The $T_{\text {gel }}$ is used to represent the gelation behavior and understand structure evolution in protein gels, and it is a critical control point in food processing when globular proteins are used to enhance viscosity or stabilize food texture, or both. Thus, knowledge of the $\mathrm{T}_{\text {gel }}$ is important in controlling the gelation process in a variety of food applications.

Because microstructure evolution is closely tied to gel formation, we hypothesized that the $\mathrm{T}_{\text {gel }}$ can be determined by observing the changes in morphology of evolving gel microstructure. Such a method would be helpful in determining the $\mathrm{T}_{\text {gel }}$ without having to interrupt or interfere with the gelation process, using in situ 
CLSM upon heating. Herein, we present such a method using $\beta$-LG, the main component of whey proteins in bovine milk.

The gelation of $\beta$-LG involves different types of interactions such as disulfide covalent links, hydrogen bonds, and hydrophobic interactions, which depend on $\mathrm{pH}$, ionic strength, and protein concentration (Kinsella and Whitehead, 1989; Ziegler and Foegeding, 1990; Aguilera, 1995; Petit et al., 2012). The gelation mechanism of globular proteins such as $\beta-\mathrm{LG}$ is generally considered a 3 -step process characterized by (1) the unfolding of protein molecules with a concomitant exposure of buried - $\mathrm{SH}$ and hydrophobic groups, (2) the aggregation of denatured protein molecules, and (3) the formation of a 3D network. The microstructural morphology of $\beta$-LG molecules shows significant changes upon heating depending on $\beta$-LG content, $\mathrm{pH}$, and $\mathrm{NaCl}$ concentration. The objectives of this study were to (1) determine the $\mathrm{T}_{\text {gel }}$ by analyzing the evolving microstructural characteristics of $\beta-\mathrm{LG}$ clusters using in situ CLSM upon heating at different gel preparation conditions: $\mathrm{pH}=2,5$, and 7 ; protein concentration $=$ 5,10 , and $15 \%$; and salt concentration $(\mathrm{NaCl})=0,0.1$, and $0.3 \mathrm{M}$ and (2) validate the $\mathrm{T}_{\text {gel }}$ values determined from CLSM by comparing them with the $\mathrm{T}_{\text {gel }}$ values determined by dynamic rheometry.

\section{MATERIALS AND METHODS}

\section{Preparation of $\beta-L G$ Solutions}

Purified bovine milk $\beta$-LG powder (BioPURE $\beta$-LG; Davisco Foods International Inc., Eden Prairie, MN) composed of $97.4 \%$ protein, $0.1 \%$ fat, and $2.4 \%$ ash (dry basis) was used. Appropriate amounts of $\beta-\mathrm{LG}$ powder were added into distilled water containing 0 , 0.1 , or $0.3 \mathrm{M} \mathrm{NaCl}$ and stirred for $2 \mathrm{~h}$ at room temperature. The $\beta-\mathrm{LG}$ solutions with protein contents of 5,10 , and $15 \%$ (wt/vol) were stored at $5^{\circ} \mathrm{C}$ overnight to hydrate the $\beta$-LG molecules completely. The $\mathrm{pH}$ of the $\beta$-LG solutions was adjusted at room temperature to 2 , 5 , and 7 [isoelectric point (pI) of $\beta-\mathrm{LG}, \sim 5.2$ ] using 1 $M \mathrm{HCl}$ or $\mathrm{NaOH}$.

\section{In Situ CLSM Imaging}

The $\beta$-LG solution prepared at each set of experimental conditions was mixed with Rhodamine B $(0.025 \%$, laser grade $99+\%$, excitation $540 \mathrm{~nm}$; emission $625 \mathrm{~nm}$, ACROS Organics, Morris Plains, NJ), which selectively forms amide bonds with the $\mathrm{N}$ terminus of amino groups in the protein with fluorescence. A drop of the dye-containing $\beta$-LG solution was placed into a concave slide glass with 0.5-mm-deep depression. After placing a coverslip on the slide glass, the $\beta$-LG specimen slide was installed on the microscope stage.

A confocal laser scanning microscope (Bio-Rad MRC 1024; Bio-Rad Inc., Hemel Hempstead, UK) attached to an inverted camera (Eclipse TE300; Nikon Inc., Tokyo, Japan) with an oil-coupled differential-interference contrast objective lens on $60 \times$ magnification was used to examine $\beta$-LG molecules in situ during gelation. Each $\beta-L G$ specimen was scanned twice to obtain noise-reduced micrographs using a Kalman filter.

A specimen temperature-control device we previously developed (Ko and Gunasekaran, 2009) was installed on the confocal laser scanning microscope to heat the $\beta$-LG solution. The temperature-control device consisted of a Peltier-installed specimen stage (Thermoelectric module CH-119-1.0-1.5; TE Technology Inc., Traverse City, $\mathrm{MI}$ ) with a 10-mm hole, a proportional-integral-derivative (PID) temperature controller (5C7-362; McShane Inc., Medina, $\mathrm{OH})$, a thermocouple (0.5-mm diameter, type T; Omega Engineering Inc., Stamford, CT), and a data logger (34970A Data Acquisition/Switch Unit; Agilent Technologies Inc., Palo Alto, CA). The thermocouple was used to continuously monitor the specimen temperature by inserting it into the $\beta$-LG solution during in situ CLSM imaging. The $\beta$-LG specimen was heated at $1^{\circ} \mathrm{C} / \mathrm{min}$ from 25 to $95^{\circ} \mathrm{C}$ under CLSM imaging. The CLSM images were continually obtained at $5^{\circ} \mathrm{C}$ increments from 50 to $95^{\circ} \mathrm{C}$. The examination area was $160.4 \times 160.4 \mu^{2}$ at $512 \times 512$ pixel resolution; each pixel represented an area of $0.313 \times 0.313 \mu \mathrm{m}^{2}$.

\section{Image Processing and Morphological Analysis}

In the CLSM images, the protein phase appears bright because it was stained using fluorescent dye. To correct for unevenness and remove noise, the images were processed using a collection of algorithms written in the Matlab computing language (R14; MathWorks Inc., Natick, MA) that we have previously published (Ko and Gunasekaran, 2007). Subsequently, the protein clusters in the processed images were segmented using IMAQ Vision Builder software (v. 6.1; National Instruments Corp., Austin, TX). The color depth of the original processed images was 256 gray level, and that of segmented images was 2 (white or black). Thus, the final images contained protein clusters as segmented objects in white, and others in black.

The morphological features (number and area) of the protein clusters were analyzed to represent the evolution of gel microstructure upon heating. The area of a segmented object was defined as the number of white pixels in it. The total area of protein clusters in a CLSM image was calculated by summing areas of all segmented objects. 


\section{Dynamic Rheometry}

Small-amplitude oscillatory shear tests were performed to probe the gelation process and determine the $\mathrm{T}_{\text {gel }}$ of $\beta$-LG systems prepared at various conditions using a dynamic rheometer (Bohlin C-VOR; Malvern Instruments Inc., East Brunswick, NJ). $\beta$-Lactoglobulin solutions prepared at different conditions were poured directly on the 20-mm parallel plate with 1-mm gap. The sample edge was covered with a thin film of paraffin oil to avoid evaporation during the measurement. The sample was heated from 25 to $100^{\circ} \mathrm{C}$ at a heating rate of $1^{\circ} \mathrm{C} / \mathrm{min}$. Upon heating, the elastic modulus $\left(\mathbf{G}^{\prime}\right)$ was measured in situ as a function of temperature at $1 \mathrm{~Hz}$ and a maximum target strain of 0.01 . All measurements were performed in triplicate for each set of gel-preparation conditions.

The $\mathrm{T}_{\text {gel }}$ from rheological data $\left(\mathbf{T}_{\text {gel } / \mathbf{R}}\right)$ was determined from the $\mathrm{G}^{\prime}$ versus temperature curve following the method proposed by Tobitani and Ross-Murphy (1997a,b). According to this method, $\mathrm{T}_{\mathrm{gel} / \mathrm{R}}$ is the temperature at which $\mathrm{G}^{\prime}$ rose above a threshold value of approximately 2 to $3 \mathrm{~Pa}$. The $\mathrm{G}^{\prime}$ rises sharply when a gelling sample goes through sol-gel transition.

\section{RESULTS AND DISCUSSION}

\section{Evolution of $\beta-L G$ Gel Microstructure Upon Heating}

Figure 1 shows the evolution of microstructure in the $5 \% \beta$-LG and $0.3 \mathrm{M} \mathrm{NaCl}$ system at $\mathrm{pH} 7$ upon heating. The $\beta$-LG clusters appear white due to staining with fluorescent dye. Initially, $\beta$-LG molecules are not visible on CLSM images because they are too small, given the limiting resolution of CLSM. However, with continued heating $\left(\sim 50^{\circ} \mathrm{C}\right), \beta$-LG molecules aggregate together, forming many individual clusters and begin to be recognized as separate entities on the CLSM micrographs. The $\beta$-LG clusters grew steadily both in number and size as the temperature increased. After a certain point, the isolated $\beta$-LG clusters began merging and subsequently combined into a matrix, which is identified as the gelation point. During this process, while the gel network continued to form, the number $\left(\mathbf{N}_{\mathrm{BLG}}\right)$ of $\beta-\mathrm{LG}$ clusters decreased but their size $\left(\mathbf{A}_{\mathrm{BLG}}\right)$ increased. The $\mathrm{A}_{\mathrm{BLG}}$ increased with the temperature, and approached a plateau. The morphology of clusters, strands, and networks showed significant changes depending on the $\beta$-LG content, $\mathrm{pH}$, and $\mathrm{NaCl}$ concentration. Details are given in the text below. Figure 2 shows marked differences in microstructures of $5 \% \beta$-LG samples prepared at different $\mathrm{pH}$ and $\mathrm{NaCl}$ concentrations.

\section{Determining $T_{\text {gel }}$ from CLSM Data}

Although the morphology of the $\beta$-LG clusters changed with respective gel preparation conditions (Figure 2) and during heating (Figure 1), it is difficult to objectively evaluate the morphological changes observed on CLSM micrographs, which is necessary to evaluate the gelation process and determine the $\mathrm{T}_{\text {gel }}$. Figure 3 is a plot of $\mathrm{N}_{\mathrm{BLG}}$ and $\mathrm{A}_{\mathrm{BLG}}$ versus temperature, along with typical CLSM images at selected temperatures for a visual comparison of the microstructural changes. The $\mathrm{N}_{\mathrm{BLG}}$ was almost zero at $50^{\circ} \mathrm{C}$, but increased with temperature, reaching a peak at around $75^{\circ} \mathrm{C}$ before decreasing and settling at $95^{\circ} \mathrm{C}$. A log-normal function (Equation 1) is commonly used to model such a pattern, which represents non-Gaussian distributions because they have more extreme events than expected for a Gaussian distribution. The log-normal distribution model is useful for representing quantities that cannot have negative values, and has been used for a variety of scientific interpretations. For example, it has been used to estimate the log-normal-shaped water retention curves to evaluate soil textures (Hwang and Choi, 2006) and to fit lag times of individual cells in bacterial populations (McKellar and Hawke, 2006). The number of clusters versus temperature data sets fit well to the log-normal model $\left(\mathrm{R}^{2}=0.92\right.$ to 1.00$)$ :

$$
y=y_{0}+p \cdot \exp \left[-0.5\left(\frac{\ln \left(\frac{x}{x_{0}}\right)}{q}\right)^{2}\right] \text {, }
$$

where $x$ is the independent variable, $y$ is the measured variable, and $q$ is a parameter related to the geometric standard deviation. The quantities $x_{0}, y_{0}$, and $p$ can be best explained with the help of a typical log-normal curve shown in Figure 4a. Because in our case $x$ is temperature and $y$ is the number of $\beta$-LG clusters, $x_{0}$ is the temperature at which $\mathrm{N}_{\mathrm{BLG}}$ is the maximum $\left(y_{\max }\right)$, and $y_{0}$ is the limiting minimum $\mathrm{N}_{\mathrm{BLG}}$. Thus, $p$ is the height of the log-normal curve (i.e., $p=y_{\max }-y_{0}$ ). Because the $T_{\text {gel }}$ may be defined as the point at which the isolated protein clusters begin to form a continuous network, $\mathrm{N}_{\mathrm{BLG}}$ should peak just around the $\mathrm{T}_{\text {gel }}$. Thus, $x_{0}$ can be likened to $\mathrm{T}_{\mathrm{gel}}$, and we name $x_{0}$ as the $\beta$-LG cluster number-based $\mathrm{T}_{\text {gel }}\left(\mathbf{T}_{\text {gel } / \mathrm{N}}\right)$.

The $\mathrm{A}_{\mathrm{BLG}}$ versus temperature curve started out being flat (i.e., $\mathrm{A}_{\mathrm{BLG}} \cong 0$ ) at $50^{\circ} \mathrm{C}$, but grew rapidly when the temperature exceeded $60^{\circ} \mathrm{C}$ before slowing down and plateauing at $95^{\circ} \mathrm{C}$. This trend is clearly sigmoidal and hence the $\mathrm{A}_{\mathrm{BLG}}$ versus temperature data sets fit 


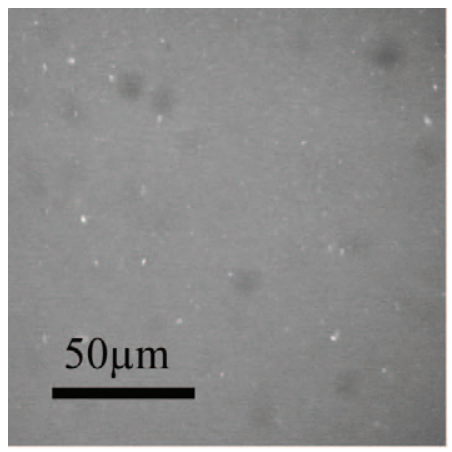

$50^{\circ} \mathrm{C}$

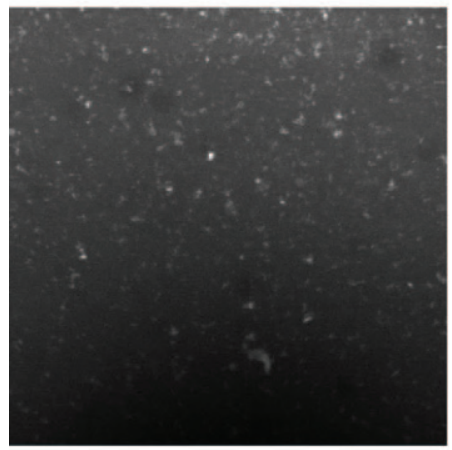

$65^{\circ} \mathrm{C}$

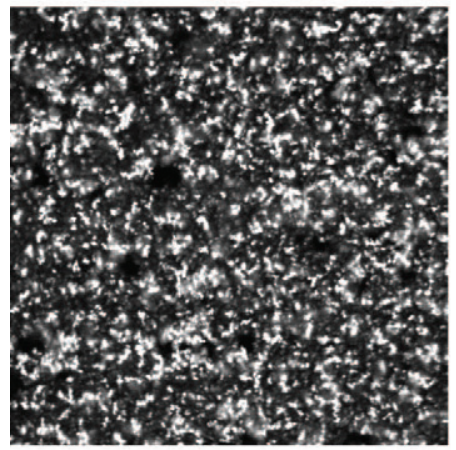

$80^{\circ} \mathrm{C}$

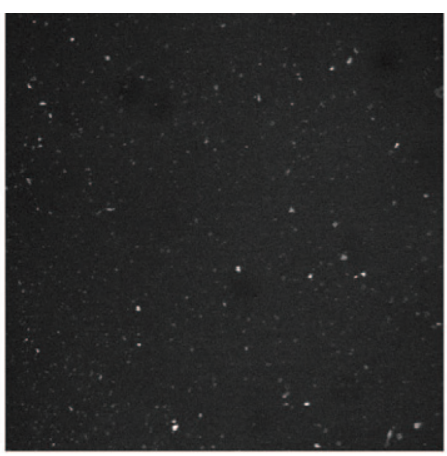

$5^{\circ} \mathrm{C}$

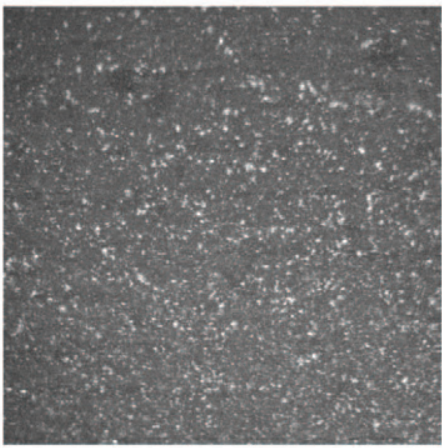

$70^{\circ} \mathrm{C}$

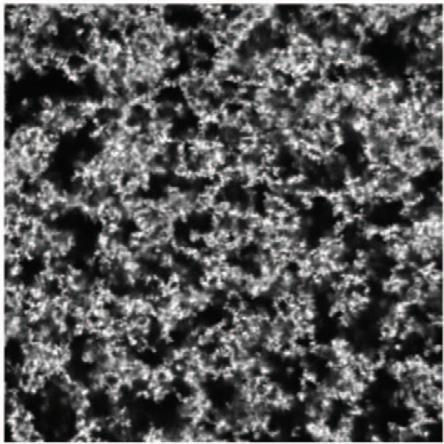

$85^{\circ} \mathrm{C}$

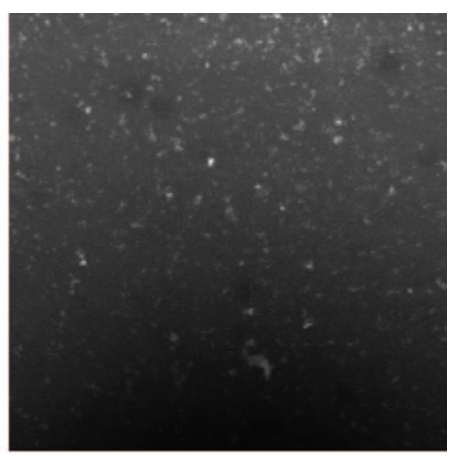

$60^{\circ} \mathrm{C}$

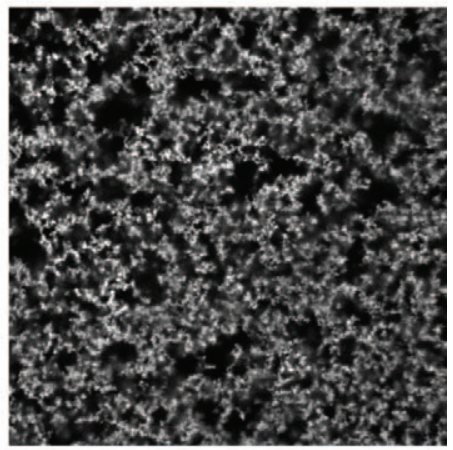

$7^{\circ} \mathrm{C}$

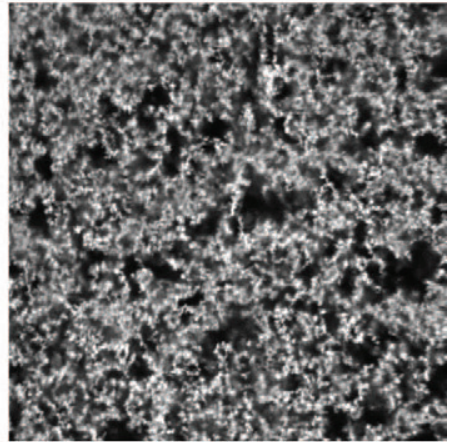

$90^{\circ} \mathrm{C}$

Figure 1. Microstructure evolution of $\beta$-LG upon heating observed using confocal laser scanning microscopy (gel system: $5 \% \beta$-LG, pH 7 , $0.3 \mathrm{M} \mathrm{NaCl}$; heating at $\left.1^{\circ} \mathrm{C} / \mathrm{min}\right)$.

extremely well $\left(\mathrm{R}^{2}=0.98\right.$ to 1.00$)$ to the sigmoid model (Equation 2):

$$
y=\frac{y_{\max }}{1+\exp \left[-\left(\frac{x-x_{1}}{s}\right)\right]},
$$

where $x$ is the independent variable; $y$ is the measured variable; $s$ is a parameter related to the steepness of the rising part of the curve; $y_{\max }$ is the maximal value of $y$, which theoretically occurs at $x=\infty$; and $x_{1}$ is the half-maximal value of $y$ [i.e., when $x=x_{1},\left(y-y_{\max }\right) / 2$ ]. These variables are illustrated in Figure 4b, a typical sigmoidal curve.

Sigmoidal functions, such as general sigmoid, logistic, Weibull, Gompertz, Hill, and Chapman models, have been used to represent sigmoidal relationships. For example, Gompertz, Weibull, and logistic models have been used to account for cell growth (Chowdhury et al., 


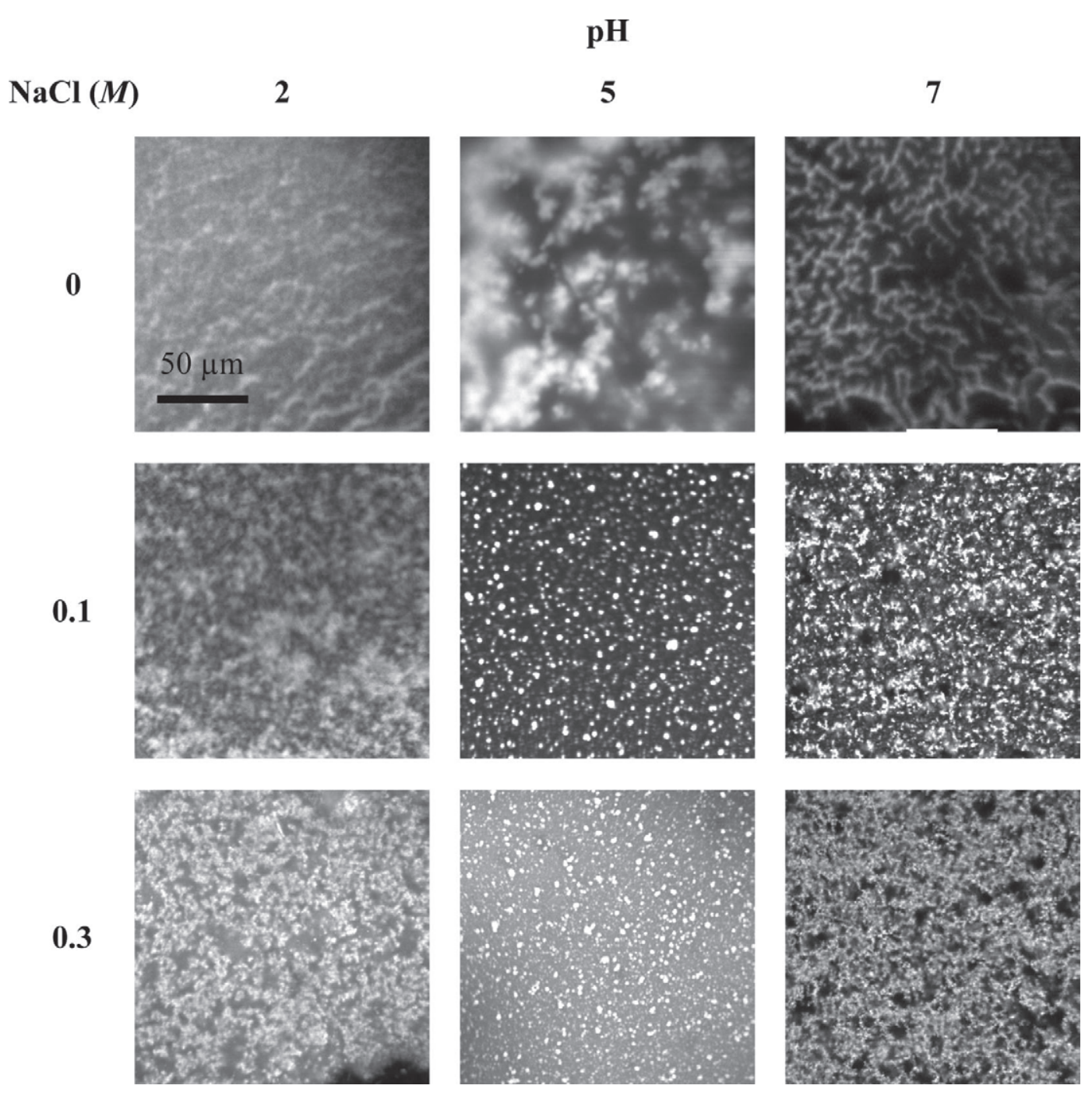

Figure 2. In situ confocal laser scanning microscopy images at $90^{\circ} \mathrm{C}$ of $5 \% \beta$-LG microstructures under different $\mathrm{pH}$ and $\mathrm{NaCl}$ concentrations.

2007), pressure inactivation (Chen, 2007), and thermal inactivation (van Boekel, 2002) of a variety of bacteria. Weibull, logistic, and Gompertz models have been used to interpret the nonlinear mixed effect on release characteristics of tablets (Adams et al., 2002).

Using the $\mathrm{A}_{\mathrm{BLG}}$ versus temperature curve, we identified the $\beta$-LG cluster area-based $\mathrm{T}_{\text {gel }}\left(\mathbf{T}_{\mathrm{gel} / \mathrm{A}}\right)$ as the temperature at which isolated $\beta$-LG clusters began to merge to form a $3 \mathrm{D}$ matrix. Thus, $\mathrm{T}_{\mathrm{gel} / \mathrm{A}}$ is the temperature corresponding to the inflection point $x_{1}$ on the sigmoidal curve where $\mathrm{A}_{\mathrm{BLG}}$ changes most rapidly.

\section{Effect of Protein Concentration, $\mathrm{pH}$, and Salt Concentration on $T_{g e l}$}

An increase in protein concentration provides an increased number of protein strands, which facilitates an easier aggregation by way of increased interactions leading to lower $\mathrm{T}_{\text {gel }}$ (Woodward and Cotterill, 1986); the effect of $\beta-L G$ content on both $T_{\text {gel } / \mathrm{N}}$ and $T_{\text {gel } / A}$ values generally support this expected trend (Figure 5). At $\mathrm{pH} 2$ and 7, the cluster size increased with protein content, affording increased chance for all interactions, including SH-SS exchange and electrostatic interactions. However, at $\mathrm{pH} 5$, the size of $\beta$-LG clusters formed was large and fairly independent of protein content, and the hydrophobic interactions are more dominant than the SH-SS exchange interactions.

The effect of $\mathrm{pH}$ was the most dominant on the $\mathrm{T}_{\text {gel }}$ for all $\beta$-LG systems, affecting both $\mathrm{T}_{\text {gel } / \mathrm{A}}$ and $\mathrm{T}_{\text {gel } / \mathrm{N}}$ similarly. The $\mathrm{T}_{\text {gel }}$ were generally the lowest at $\mathrm{pH} 2$ and the highest at $\mathrm{pH} 5$, considering the data at the 3 $\mathrm{pH}$. At $\mathrm{pH} 5$, the $\mathrm{T}_{\text {gel }}$ were insensitive to $\beta$-LG and salt content, as it was near the pI of $\beta$-LG. The morphology of evolving $\beta$-LG clusters (Figure 2 ) are strongly dependent on the balance between attractive and repulsive 


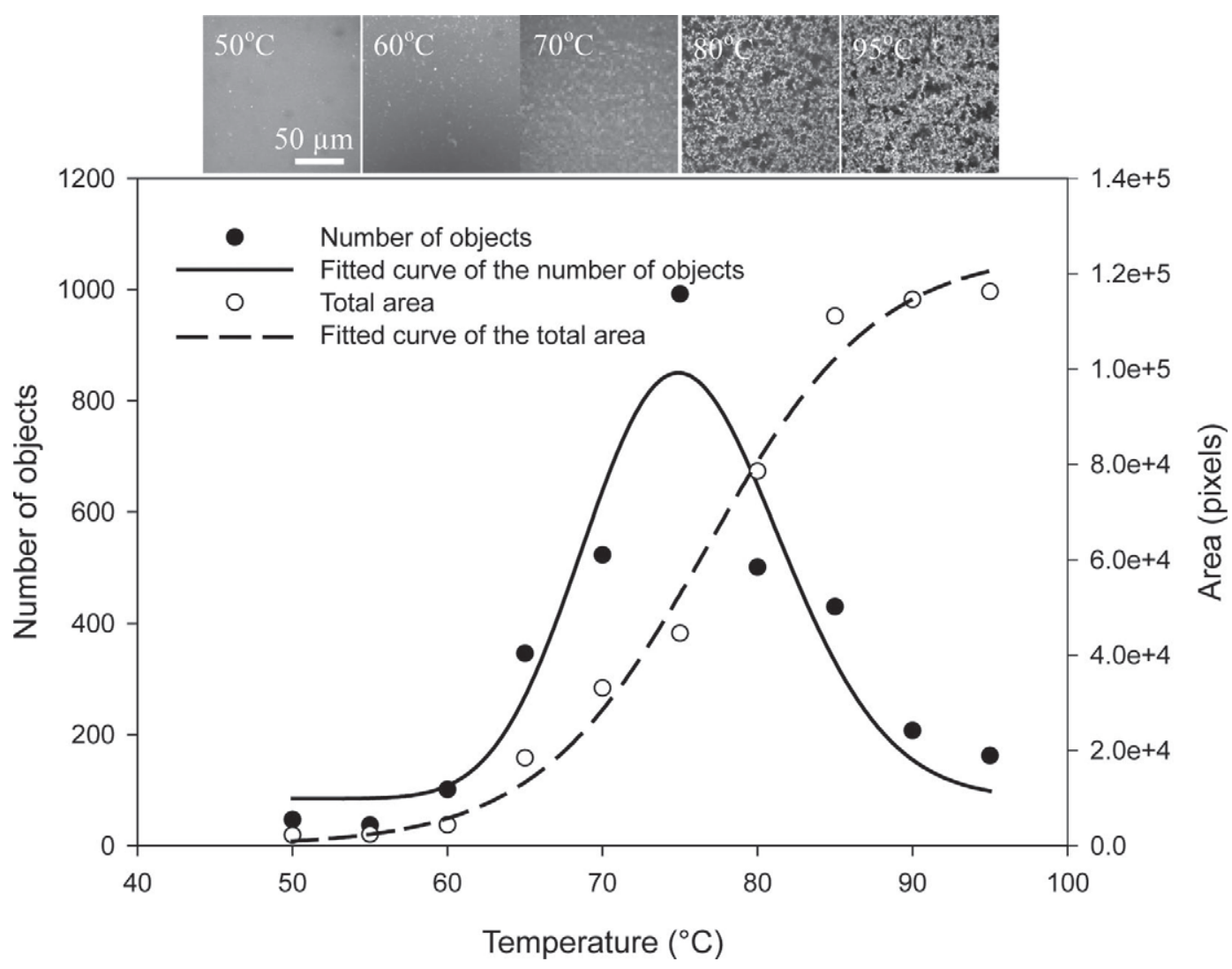

Figure 3. Typical morphological changes in $\beta$-LG clusters upon heating as observed on confocal laser scanning microscopy micrographs and the fitted curves (gel system: $5 \% \beta-\mathrm{LG}, \mathrm{pH} 7,0.3 \mathrm{M} \mathrm{NaCl}$; heating at $1^{\circ} \mathrm{C} / \mathrm{min}$ ).

conditions, which result in fine-stranded or particulate aggregates or their mixtures, depending on the $\mathrm{pH}$ (Clark et al., 1981; Langton and Hermansson, 1992; Stading et al., 1992, 1993; Kavanagh et al., 2000; Mudgal et al., 2011). The $\mathrm{pH}$ affects a balance between the attractive forces arising from unfolding of $\beta$-LG molecules and the repulsive electrostatic forces due to the initial net charge of $\beta$-LG molecules (Schmitt et al., 2009). At $\mathrm{pH} 2$ and $7, \beta-\mathrm{LG}$ molecules stabilized by positive or negative charges, respectively, are hardly aggregated. At $\mathrm{pH} 2$, the hydrophobic interactions promote to make $\beta$-LG aggregates, which easily form clusters even at low temperature. At $\mathrm{pH} 7$, the $\beta$-LG molecules could hardly aggregate at low temperature, but aggregate more readily at high temperature (Ko and Gunasekaran, 2009). The transition between fine-stranded and particulate gels is caused by a switch from net repulsive to net attractive interaction between growing $\beta$-LG aggregates (Ako et al., 2009). Linear-stranded clusters are formed at $\mathrm{pH} 7$ due to SH-SS exchange reactions among $\beta$-LG molecules, which are much larger than the $\beta$-LG clusters formed at acidic pH (Liu et al., 1994). In contrast, at $\mathrm{pH} 5$, the $\beta$-LG molecules are less charged and, therefore, hydrophobic interactions are enhanced, whereas the SH-SS exchange reactions are suppressed. Recently, Schmitt et al. (2009) reported the effect of $\mathrm{pH}$ upon heating on $\beta$-LG aggregates by dynamic light scattering and Fourier transform infrared spectroscopy; large insoluble $\beta$-LG particulates were formed between $\mathrm{pH} 4.6$ and 5.8, whereas soluble aggregates were formed at $\mathrm{pH}<4.6$ or $>5.8$ (Schmitt et al., 2009).

The salt content of the $\beta$-LG system also has a significant effect on $\mathrm{T}_{\text {gel }}$. Overall, at $\mathrm{pH} 2, \mathrm{~T}_{\text {gel }}$ decreased with increasing salt content, yielding the lowest $\mathrm{T}_{\text {gel }}$ at $0.3 \mathrm{M} \mathrm{NaCl}$ at all protein contents. As the addition of salt reduces the electrostatic repulsion among $\beta$-LG molecules, they aggregate easily at the lower temperature; at $\mathrm{pH} 2$, hydrophobic interactions are promoted, which leads to the lowering of $\mathrm{T}_{\text {gel }}$. At $\mathrm{pH} 7$ and $15 \%$ $\beta$-LG content, $\mathrm{T}_{\mathrm{gel} / \mathrm{N}}$ and $\mathrm{T}_{\mathrm{gel} / \mathrm{A}}$ decreased significantly with addition of salt up to $0.1 \mathrm{M}$ concentration; however, further addition up to $0.3 \mathrm{M}$ concentration resulted in an increase in $\mathrm{T}_{\text {gel }}$. This suggests a critical salt concentration around which the electrostatic repulsion starts to increase or decrease with salt content, and $T_{\text {gel }}$ changes inversely with increasing salt concentration. These results are in agreement with a recent report by Ako et al. (2009), who investigated the effect of differ- 
(a) Log-normal plot

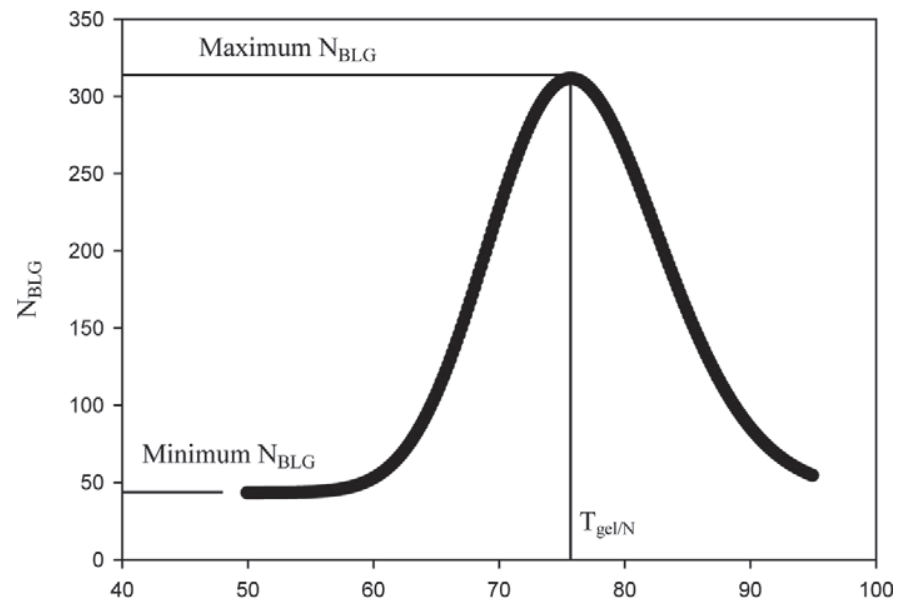

(b) Sigmoid plot

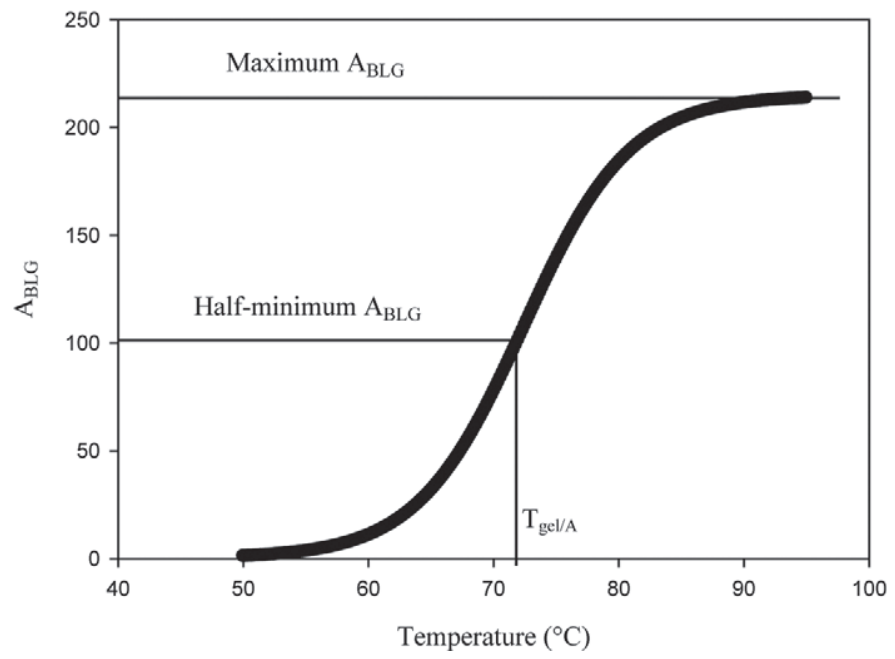

Figure 4. Typical plots of (a) log-normal and (b) sigmoid models and their characteristics. $\mathrm{N}_{\mathrm{BLG}}=$ number of $\beta$-LG clusters; $\mathrm{A}_{\mathrm{BLG}}=$ size of $\beta$-LG clusters; $\mathrm{T}_{\mathrm{gel} / \mathrm{N}}=$ number-based gelation temperature; $\mathrm{T}_{\mathrm{gel} / \mathrm{A}}=$ area-based gelation temperature.

ent $\mathrm{NaCl}$ concentrations on $\beta$-LG gels upon heating at $\mathrm{pH} 7$ using CLSM; $\beta$-LG gels formed were homogeneous at below $0.2 \mathrm{M} \mathrm{NaCl}$, whereas large aggregates with high $\beta$-LG density appeared due to increased attractive interactions. These results agree with a previous rheological study showing that the $\mathrm{G}^{\prime}$ of protein gel decreased with increasing salt content above a critical limit (Foegeding et al., 1995; Twomey et al., 1997). At those conditions, less electrostatic repulsion exists because salt ions shield the charges on the surface of protein molecules. The conformational change of $\beta$-LG through masking of the -SH group reduces its capacity to undergo SH-SS exchange. Therefore, protein-protein interactions increase and strengthen hydrophobic in- teractions and protein-water interactions are screened. Thus, the combined effect of protein content, $\mathrm{pH}$, and salt concentration determines the $\mathrm{T}_{\text {gel }}$ of $\beta-\mathrm{LG}$ and such combined effects should be accounted for.

\section{Validation of $T_{\text {gel }}$ Determined Based on Gel Microstructure}

The validity of $T_{\text {gel } / \mathrm{N}}$ and $T_{\text {gel } / \mathrm{A}}$ as the $T_{\text {gel }}$ of the $\beta-L G$ system was verified by comparing them against $T_{\text {gel } / R}$ values determined experimentally from $G^{\prime}$ versus temperature response of the $\beta$-LG system during heating (Figure 6). The correlation of $\mathrm{T}_{\text {gel } / \mathrm{N}}$ versus $\mathrm{T}_{\mathrm{gel} / \mathrm{R}}$ was higher $\left(R^{2}=0.85\right)$ than that of $T_{\text {gel/A }}$ versus $T_{\text {gel } / R}$ $\left(R^{2}=0.72\right)$. Based on these results, $T_{\text {gel } / \mathrm{N}}$ appears to be fairly good representative of the traditionally measured $\mathrm{T}_{\mathrm{gel}}, \mathrm{T}_{\mathrm{gel} / \mathrm{R}}$.

Furthermore, $T_{\text {gel } / \mathrm{N}}$ and $\mathrm{T}_{\mathrm{gel} / \mathrm{A}}$ values were compared with $\mathrm{T}_{\mathrm{gel} / \mathrm{R}}$ values reported in the literature. Hines and Foegeding (1993) studied gelation of $7 \%$ (wt/vol) $\beta-L G$ solution in $50 \mathrm{~m} M$ TES buffer with $100 \mathrm{~m} M \mathrm{NaCl}$ at $\mathrm{pH}$ 7.0. This $\beta$-LG system is similar to a set of experimental conditions we studied $(\mathrm{pH} 7$ and $0.1 \mathrm{M} \mathrm{NaCl})$ except for the $\beta$-LG concentration. The $\beta$-LG sample was heated at $1^{\circ} \mathrm{C} / \mathrm{min}$, from 25 to $80^{\circ} \mathrm{C}$, and held for 180 min at $80^{\circ} \mathrm{C}$ in the rheometer. They reported a $\mathrm{T}_{\mathrm{gel} / \mathrm{R}}$ of $79.4^{\circ} \mathrm{C}$ (Figure $5 \mathrm{~h}$, filled squares), which is fairly similar to the $\mathrm{T}_{\text {gel } / \mathrm{N}}$ and $\mathrm{T}_{\mathrm{gel} / \mathrm{A}}$ values we determined, when interpolated for 7\% $\beta$-LG concentration. Gezimati et al. (1997) reported a $\mathrm{T}_{\mathrm{gel} / \mathrm{R}}$ of $82^{\circ} \mathrm{C}$ for $10 \%$ (wt/vol) $\beta$-LG solution in a buffer during heating from 25 to $90^{\circ} \mathrm{C}$ at $1^{\circ} \mathrm{C} / \mathrm{min}$ (Figure $5 \mathrm{~h}$, open squares). The buffer was composed of $2.03 \mathrm{~g}$ of $\mathrm{K}_{2} \mathrm{HPO}_{4}, 0.63 \mathrm{~g}$ of $\mathrm{NaCl}, 2.06 \mathrm{~g}$ of trisodium citrate dihydrate, $1.31 \mathrm{~g}$ of $\mathrm{CaCl}_{2} \cdot 2 \mathrm{H}_{2} \mathrm{O}$, and $8.0 \mathrm{~g}$ of lactose made up to $1 \mathrm{~L}$ and adjusted to $\mathrm{pH}$ 6.8. The $\mathrm{T}_{\text {gel } / \mathrm{R}}$ reported was higher than all the $T_{\text {gel }}$ we determined. Different ions and excessive lactose present in the $\beta$-LG system of Gezimati et al. (1997) may have been the reason for the higher $\mathrm{T}_{\mathrm{gel} / \mathrm{R}}$ in their study.

Stading and Hermansson (1990) determined $\mathrm{T}_{\mathrm{gel} / \mathrm{R}}$ values of $12 \%$ (wt/vol) $\beta$-LG aqueous solutions at different $\mathrm{pH}$ by heating up to $95^{\circ} \mathrm{C}$. The $\mathrm{T}_{\mathrm{gel} / \mathrm{R}}$ values reported were $72,77,80,60,40,68,80$, and $95^{\circ} \mathrm{C}$ at $\mathrm{pH} 2.5,3.0,4.2,4.5,5.5,5.8,6.5$, and 7.5 , respectively (Figure 5a, d, and g, open circles). Their values at $\mathrm{pH}$ $2.5,3.0$, and 6.5 are similar to the $\mathrm{T}_{\mathrm{gel} / \mathrm{N}}, \mathrm{T}_{\mathrm{gel} / \mathrm{A}}$, and $\mathrm{T}_{\mathrm{gel} / \mathrm{R}}$ values we determined, if 5 and $10 \% \beta$-LG concentration data were extrapolated to $12 \%$ concentration; however, their $\mathrm{T}_{\mathrm{gel} / \mathrm{R}}$ values at $\mathrm{pH} 4.2,4.5$, and 5.5 were much lower. At these $\mathrm{pH}$, the $\mathrm{T}_{\text {gel }}$ we determined were hardly comparable even though the $\mathrm{pH}$ was not much different. In the $\mathrm{pH}$ range of 4 to $5, \beta-\mathrm{LG}$ forms a gel at relatively low temperature. The $\beta-\mathrm{LG}$ gelation is 


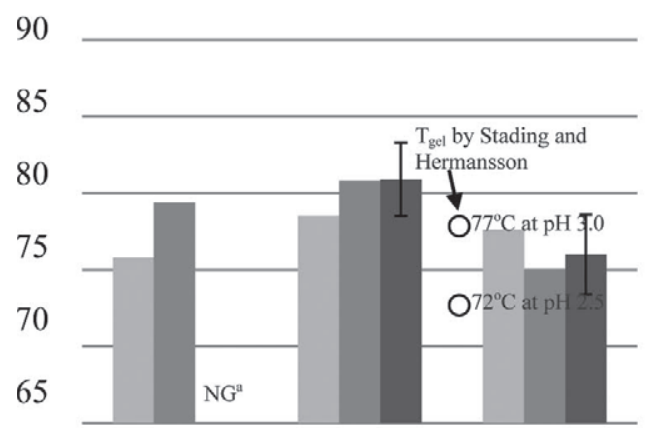

(d) $\mathrm{pH} 5, \mathrm{NaCl} 0 \mathrm{M}$

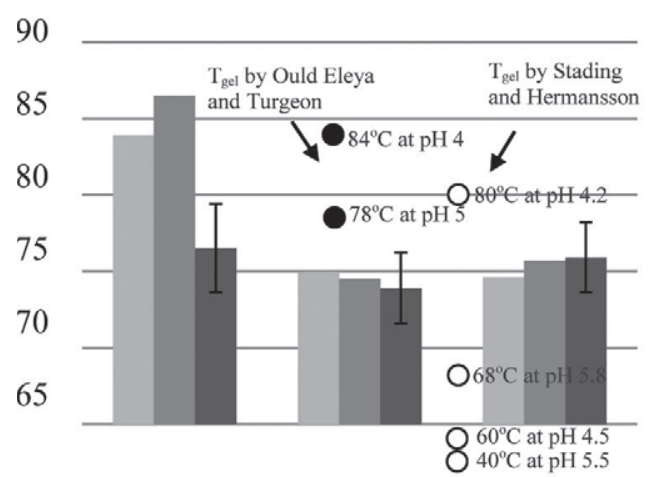

(g) $\mathrm{pH} 7, \mathrm{NaCl} 0 M$

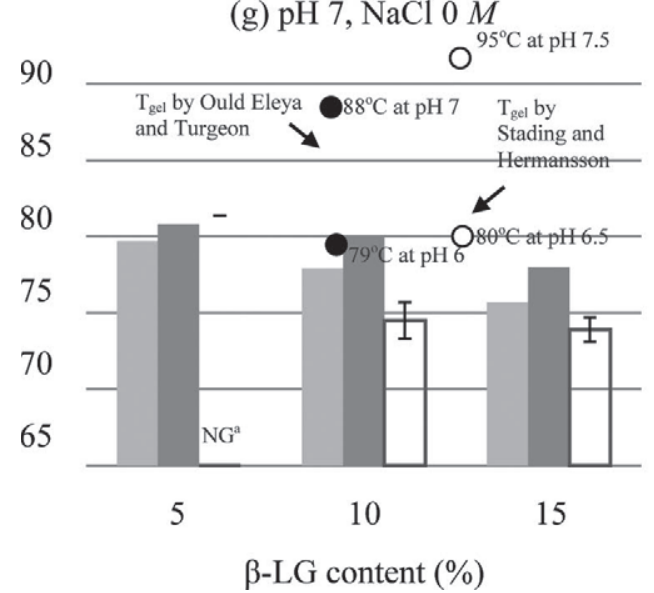

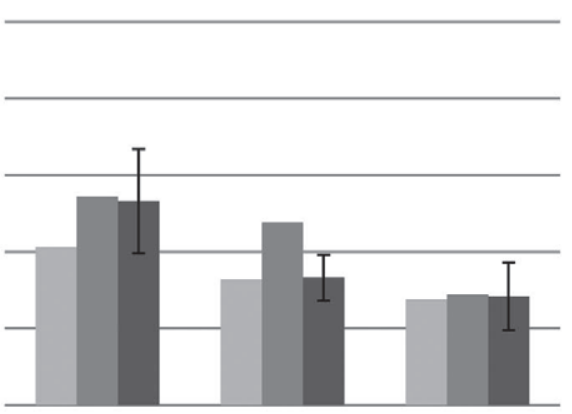

(e) $\mathrm{pH} 5, \mathrm{NaCl} 0.1 \mathrm{M}$

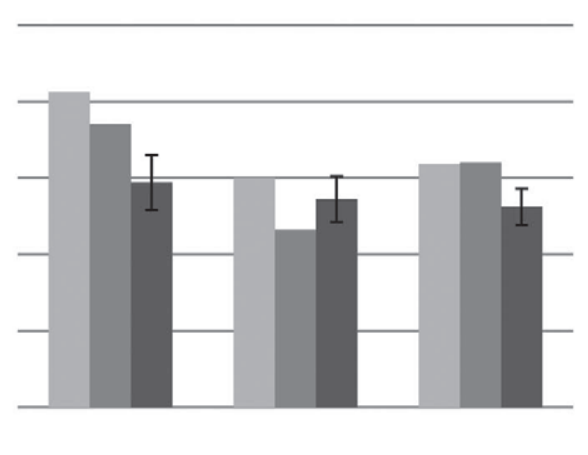

(h) $\mathrm{pH} 7, \mathrm{NaCl} 0.1 \mathrm{M}$

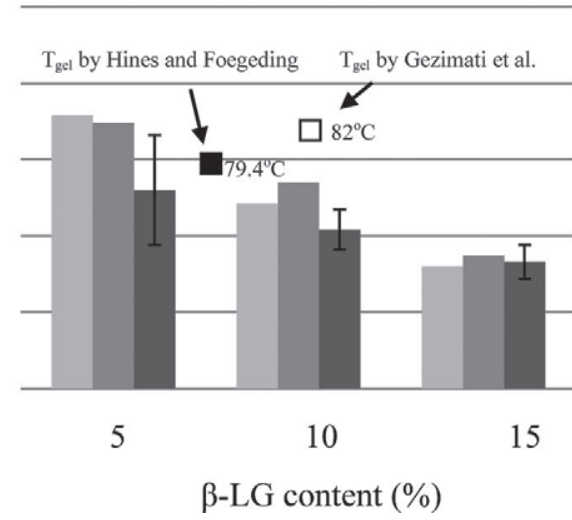

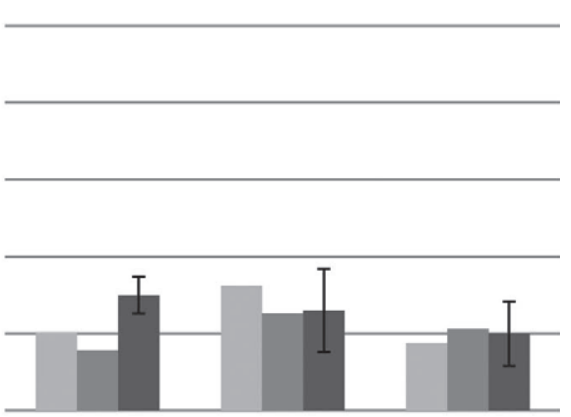

(f) $\mathrm{pH} 5, \mathrm{NaCl} 0.3 \mathrm{M}$

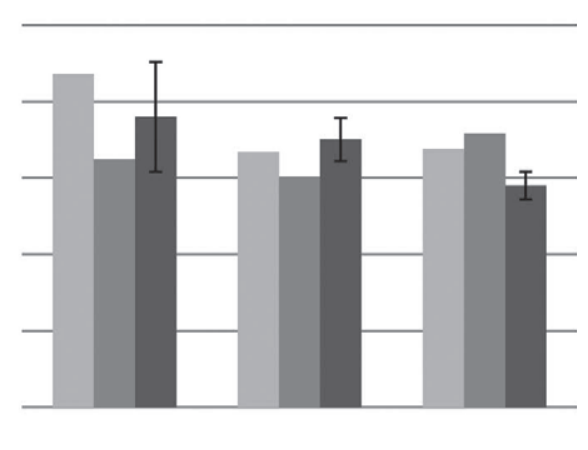

(i) $\mathrm{pH} 7, \mathrm{NaCl} 0.3 \mathrm{M}$

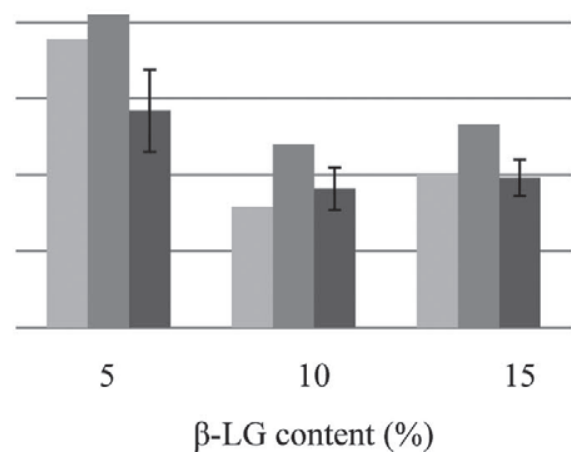

Figure 5. Gelation temperatures $\left(\mathrm{T}_{\text {gel }}\right)$ determined by in situ confocal laser scanning microscopy [number-based gelation temperature $\left(\mathrm{T}_{\text {gel }} / \mathrm{N}\right)$, light gray bars; area-based gelation temperature $\left(\mathrm{T}_{\text {gel } / \mathrm{A}}\right)$, medium gray bars] and those reported in the literature [Stading and Hermansson (1990), Ould Eleya and Turgeon (2000), Hines and Foegeding (1993), and Gezimati et al. (1997)] via dynamic rheometry ( $\mathrm{T}_{\text {gel/R}}$; dark gray bars) for $\beta$-LG gels. ${ }^{a} \mathrm{NG}=$ no gelation.

sensitive to temperature or heat at $\mathrm{pH}$ close to the $\mathrm{pI}$ of $\beta$-LG, where strong hydrophobic interactions result in gelation, even at relatively low temperature. In contrast, at $\mathrm{pH} 2.5,3.0$, and 6.5 , far from the $\mathrm{pI}$, our $\mathrm{T}_{\text {gel }}$ were similar to the $\mathrm{T}_{\mathrm{gel} / \mathrm{R}}$ values at $\mathrm{pH} 4.2,4.5$, and 5.5 determined by Stading and Hermansson (1990).
Ould Eleya and Turgeon (2000) also studied the effect of $\mathrm{pH}$ ( 4 to 7 ) on the gelation of $10 \% \beta$-LG. The $\mathrm{T}_{\mathrm{gel} / \mathrm{R}}$ values were $84,78,79$, and $88^{\circ} \mathrm{C}$ for $\mathrm{pH} 4,5$, 6 , and 7 , respectively (Figure $5 \mathrm{~d}$ and g, filled circles). These values, similar to those of Gezimati et al. (1997), were higher than all $\mathrm{T}_{\text {gel }}$ values we determined. Dif- 


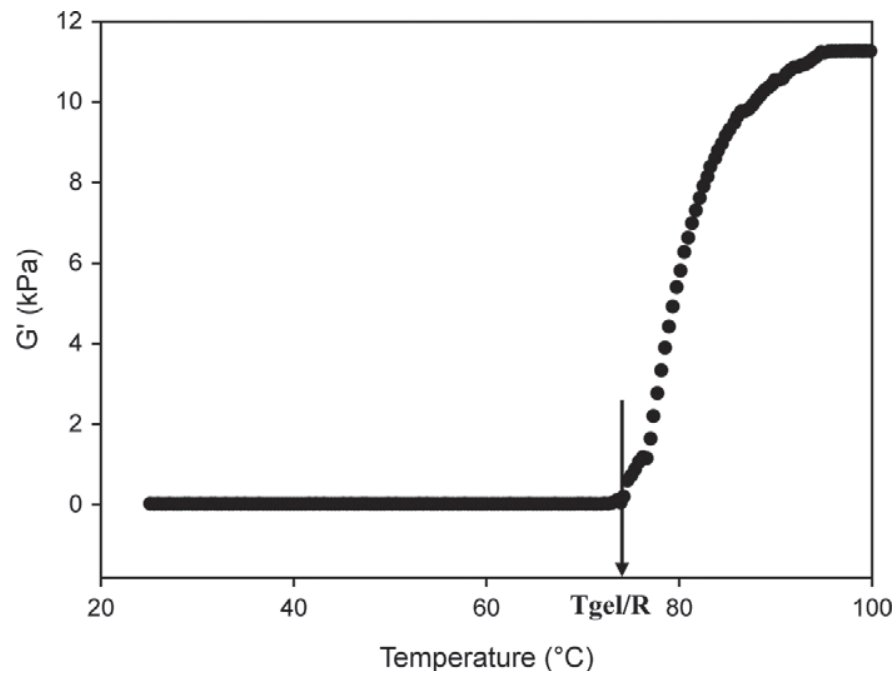

Figure 6. Typical elastic modulus $\left(\mathrm{G}^{\prime}\right)$ response from dynamic rheological measurement showing the determination of rheological gelation temperature $\left(\mathrm{T}_{\mathrm{gel} / \mathrm{R}}\right)$ at the point where $\mathrm{G}^{\prime}$ begins to exceed a threshold value (gel system: $10 \% \beta-\mathrm{LG}, 0.1 \mathrm{M} \mathrm{NaCl}, \mathrm{pH} 7$; heating at $\left.1^{\circ} \mathrm{C} / \mathrm{min}\right)$.

ferent solvent- $\beta$-LG interactions from the preparation conditions in the current study may have caused the differences in the $\mathrm{T}_{\mathrm{gel}}$.

Determining the $\mathrm{T}_{\text {gel }}$ by CLSM has a limit under conditions where no gel is formed. The $\mathrm{T}_{\mathrm{gel} / \mathrm{N}}$ and $\mathrm{T}_{\mathrm{gel} / \mathrm{A}}$ of $5 \% \beta$-LG aqueous solutions were determined at $\mathrm{pH}$ 2 or 7 , whereas $\mathrm{T}_{\text {gel } / \mathrm{R}}$ did not appear. In these cases, large discrepancies existed between the $\mathrm{T}_{\text {gel }}\left(\mathrm{T}_{\text {gel } / \mathrm{N}}\right.$ and $\left.\mathrm{T}_{\text {gel } / \mathrm{A}}\right)$ determined by the CLSM method and the $\mathrm{T}_{\text {gel }}$ $\left(\mathrm{T}_{\mathrm{gel} / \mathrm{R}}\right)$ determined by rheometry. Nevertheless, $\mathrm{T}_{\mathrm{gel} / \mathrm{N}}$ and $T_{\mathrm{gel} / \mathrm{A}}$ generally agreed well with $\mathrm{T}_{\mathrm{gel} / \mathrm{R}}$ when the $\beta$-LG aqueous solutions with sufficient protein concentration evolved gel structures.

\section{CONCLUSIONS}

Evolution of microstructure during heat-induced gelation of $\beta$-LG was observed in situ using CLSM. The number and area of $\beta$-LG clusters increased upon heating and subsequently formed a continuous network, after which the number of $\beta$-LG clusters decreased but their size increased. This evolving gel morphology was investigated by analyzing the temperature-dependent number and total area of $\beta$-LG clusters observed on micrographs and by determining respective $\mathrm{T}_{\text {gel }}\left(\mathrm{T}_{\text {gel } / \mathrm{N}}\right.$ and $\left.T_{\text {gel } / \mathrm{A}}\right)$. These $\mathrm{T}_{\text {gel }}$ revealed a substantial dependence of the gelation properties of $\beta$-LG on the preparation conditions, including protein content, $\mathrm{pH}$, and salt concentration. The results generally agreed well with corresponding results obtained via dynamic rheometry and the values reported in the literature. Thus, in situ microscopy is a valid method to determine the $\mathrm{T}_{\text {gel }}$ of globular proteins.

\section{ACKNOWLEDGMENTS}

This study was partly supported by the Technology Development Program for Agriculture and Forestry, Ministry for Food, Agriculture, Forestry and Fisheries (no. 20083061), Republic of Korea.

\section{REFERENCES}

Adams, E., D. Coomans, J. Smeyers-Verbeke, and D. L. Massart. 2002. Non-linear mixed effects models for the evaluation of dissolution profiles. Int. J. Pharm. 240:37-53.

Aguilera, J. M. 1995. Gelation of whey proteins. Food Technol. 49:83-86,88-89.

Ako, K., D. Durand, T. Nicolai, and L. Becu. 2009. Quantitative analysis of confocal laser scanning microscopy images of heat-set globular protein gels. Food Hydrocoll. 23:1111-1119.

Chen, H. 2007. Use of linear, Weibull, and log-logistic functions to model pressure inactivation of seven foodborne pathogens in milk. Food Microbiol. 24:197-204.

Chowdhury, B. R., R. Chakraborty, and U. R. Chaudhuri. 2007. Validity of modified Gompertz and logistic models in predicting cell growth of Pediococcus acidilactici $\mathrm{H}$ during the production of bacteriocin pediocin AcH. J. Food Eng. 80:1171-1175.

Clark, A. H., F. J. Judge, J. B. Richards, J. M. Stubbs, and A. Suggett. 1981. Electron microscopy of network structures in thermally-induced globular protein gels. Int. J. Pept. Protein Res. 17:380-392.

Emmons, D. B., M. Kalab, E. Larmond, and R. J. Lowrie. 1980. Milk gel structure. 10. Texture and microstructure in Cheddar cheese made from whole milk and from homogenized low-fat milk. J. Texture Stud. 11:15-34.

Foegeding, E. A., E. L. Bowland, and C. C. Hardin. 1995. Factors that determine the fracture properties and microstructure of globular protein gels. Food Hydrocoll. 9:237-249.

Gezimati, J., L. K. Creamer, and H. Singh. 1997. Heat-induced interactions and gelation of mixtures of $\beta$-lactoglobulin and $\alpha$-lactalbumin. J. Agric. Food Chem. 45:1130-1136.

Heinemann, M., T. Wagner, B. Doumèche, M. Ansorge-Schumacher, and J. Büchs. 2002. A new approach for the spatially resolved qualitative analysis of the protein distribution in hydrogel beads based on confocal laser scanning microscopy. Biotechnol. Lett. $24: 845-850$.

Hines, M. E., and E. A. Foegeding. 1993. Interactions of $\alpha$-lactalbumin and bovine serum albumin with $\beta$-lactoglobulin in thermally induced gelation. J. Agric. Food Chem. 41:341-346.

Holcomb, D. N. 1991. Structure and rheology of dairy products: A compilation of references with subject and author indexes. Food Struct. 10:45-108.

Hwang, S. I., and S. I. Choi. 2006. Use of a lognormal distribution model for estimating soil water retention curves from particle-size distribution data. J. Hydrol. (Amst.) 323:325-334.

Kavanagh, G. M., A. H. Clark, and S. B. Ross-Murphy. 2000. Heatinduced gelation of globular proteins: 4. Gelation kinetics of low $\mathrm{pH}$ 3-lactoglobulin gels. Langmuir 16:9584-9594.

Kinsella, J. E., and D. M. Whitehead. 1989. Protein in whey: Chemical, physical, and functional properties. Adv. Food Nutr. Res. $33: 343-438$

Ko, S., and S. Gunasekaran. 2007. Error correction of confocal microscopy images for in situ food microstructure evaluation. J. Food Eng. 79:935-944.

Ko, S., and S. Gunasekaran. 2009. In situ microstructure evaluation during gelation of $\beta$-lactoglobulin. J. Food Eng. 90:161-170.

Langton, M., and A. M. Hermansson. 1992. Fine-stranded and particulate gels of $\beta$-lactoglobulin and whey-protein at varying $\mathrm{pH}$. Food Hydrocoll. 5:523-539. 
Liu, T. X., P. Relkin, and B. Launay. 1994. Thermal denaturation and heat-induced gelation properties of $\beta$-lactoglobulin. Effects of some chemical parameters. Thermochim. Acta 246:387-403.

McKellar, R. C., and A. Hawke. 2006. Assessment of distributions for fitting lag times of individual cells in bacterial populations. Int. J. Food Microbiol. 106:169-175.

Mudgal, P., C. R. Daubert, and E. A. Foegeding. 2011. Kinetic study of $\beta$-lactoglobulin thermal aggregation at low pH. J. Food Eng. 106:159-165.

Ould Eleya, M. M., and S. L. Turgeon. 2000. The effects of pH on the rheology of $\beta$-lactoglobulin/ $\kappa$-carrageenan mixed gels. Food Hydrocoll. 14:245-251.

Petit, J., A.-L. Herbig, A. Moreau, J.-F.. Le-Page, T. Six, and G. Delaplace. 2012. Granulomorphometry: A suitable tool for identifying hydrophobic and disulfide bonds in $\beta$-lactoglobulin aggregates. Application to the study of $\beta$-lactoglobulin aggregation mechanism between 70 and $95^{\circ}$ C. J. Dairy Sci. 95:4188-4202.

Schmitt, C., C. Bovay, A.-M. Vuilliomenet, M. Rouvet, L. Bovetto, R. Barbar, and C. Sanchez. 2009. Multiscale characterization of individualized $\beta$-lactoglobulin microgels formed upon heat treatment under narrow $\mathrm{pH}$ range conditions. Langmuir 25:7899-7909.

Stading, M., and A.-M. Hermansson. 1990. Viscoelastic behaviour of $\beta$-lactoglobulin gel structures. Food Hydrocoll. 4:121-135.
Stading, M., M. Langton, and A.-M. Hermansson. 1992. Inhomogeneous fine-stranded $\beta$-lactoglobulin gels. Food Hydrocoll. 6:455470.

Stading, M., M. Langton, and A. M. Hermansson. 1993. Microstructure and rheological behavior of particulate $\beta$-lactoglobulin gels. Food Hydrocoll. 7:195-212.

Tobitani, A., and S. B. Ross-Murphy. 1997a. Heat-induced gelation of globular proteins. 1. Model for the effects of time and temperature on the gelation time of BSA gels. Macromolecules 30:4845-4854.

Tobitani, A., and S. B. Ross-Murphy. 1997b. Heat-induced gelation of globular proteins. 2. Effect of environmental factors on single-component and mixed-protein gels. Macromolecules 30:4855-4862.

Twomey, M., M. K. Keogh, R. Mehra, and B. T. O'Kennedy. 1997. Gel characteristics of $\beta$-lactoglobulin, whey protein concentrate and whey protein isolate. J. Texture Stud. 28:387-403.

van Boekel, M. A. 2002. On the use of the Weibull model to describe thermal inactivation of microbial vegetative cells. Int. J. Food Microbiol. 74:139-159.

Woodward, S. A., and O. J. Cotterill. 1986. Texture and microstructure of heat-formed egg-white gels. J. Food Sci. 51:333-339.

Ziegler, G. R., and E. A. Foegeding. 1990. The gelation of proteins. Adv. Food Nutr. Res. 34:203-298. 